\title{
Evaluating Engineering Properties of Marine Clay Soil at Malacca and Proposed Methods of Quality Enhancement
}

\author{
Ahmed Hassan Saad ${ }^{1}$, Haslinda Nahazanan ${ }^{2}$, Zainuddin Md Yusoff ${ }^{1}$, Muskhazli Mustafa ${ }^{3}$ \\ ${ }^{1}$ Department of Civil Engineering, Faculty of Engineering, Putra Malaysia University \\ ${ }^{2}$ Department of Civil Engineering, Faculty of Engineering, Putra Malaysia University, n_haslinda@upm.edu.my \\ ${ }^{3}$ Department of Biology, Faculty of Science, Putra Malaysia University
}

\begin{abstract}
Malacca City is located along the western coastline of Peninsular Malaysia and lays on a foundation of soft marine clay. In studying the soil properties of the state of Malacca, samples were taken at a depth of 2.5 meters from the ground surface, whereby the water level was encountered at 1.0-meter depth following the water level of the Malacca river. Soil testing was performed on the collected samples to identify geotechnical parameters as an indication of Malacca marine clay properties and were compared to the engineering parameters of South East Asia marine clays. As per the comparison, the laboratory results have shown that the Malacca marine clay was found to be following the average general trend of identical engineering properties for the other marine clays considered in this research paper. Water content was found to be $74.15 \%$, liquid limit $75.3 \%$, plastic limit $35 \%$, plasticity index 41.55 , compressibility index 3.780 $\mathrm{m}^{2} / \mathrm{yr}$ compression index 0.948 , swelling index 0.174 , and preconsolidation stress $103.54 \mathrm{kPa}$, and specific gravity 2.60 . Different types of soil improvement were also reviewed in terms of their limitations, required scale of application, cost, time, and environmental restrictions to find the most suitable method to improve the engineering properties of Malacca marine clay.
\end{abstract}

Key words : Clay, Geotechnical parameters, Malacca, Marine Clay, Soil improvement, Soil investigation.

\section{INTRODUCTION}

Marine clay is a type of soil that is very sensitive to imposed load, whereby any deformations resulted is significant. However, predicting the development of deformations and excess pore water pressure during the loading process is difficult to be achieved [1]. Therefore, it renders marine clay a problematic soil that affects their existing and proposed structure safety, stability, and sustainability, as well as resulting in ambiguous behavior. Marine clays are typically found in regions of the coastlines, shores of lakes, and banks of rivers, which can be translated to have very high water content compared to its liquid limit in some cases. Therefore, void ratio values are deemed as significant as it makes the soil compressibility extremely high to the extent unstable deformations are generated, especially under non-uniform loading stresses. Furthermore, a high groundwater table is commonly encountered in these areas, which displays a bulk density significantly bigger than their dry density. It will alter the stresses upon the utilities present in the soil, especially those that are subjected to uplift force and are under the repeated cycles of loading and unloading. In this scenario, both the utilities and soil inevitably fail together or separately, according to which that is weaker. These properties are common for marine clays, with the region of South Asia following the same trending and tendencies [2]-[4].

The main minerals that formulate the marine clay in South Asia are smectite, vermiculite, kaolinite, halloysite, and mica [4]-[11]. Each region possesses marine clay having different ratios of these minerals, which results in their different behavior due to these ratios. Smectite, in particular, is a common and sensitive mineral that functions to clarify the highwater content values for marine clays. Regardless of the types of minerals forming the marine clay, it becomes extremely grueling to engage in either establishing the new structures of the immersed tunnel of Hong Kong-Zhuhai-Macao-Bridge (HZMB) [12] and Shanghai metro station [13] or curing these structures after failure as significant as in the settlements of the Shanghai metro line [14].

In the context of Peninsular Malaysia, soil formation of its western coastline is characterized by the soft soil of peats, organic soils, and marine and riverine alluvium [15]. This coastal line is also occupied by Malacca, which is located about $120 \mathrm{~km}$ away to the south of Kuala Lumpur. It is an important port in South-Asia due to its attractive role for tourism as a historical city and port alike. The city lies on soft marine clay layers that affect the structures established on top of it, which is subsequently perceived as a challenge in proposing future structures.

Various methods were proposed to treat marine clay soils to enhance its characteristics. The void ratio was reduced by 
water content reduction [7], [16]-[19], while others add materials to increase soil shear strength [6], [8], [18], [20], [21].

\section{MATERIALS AND METHODS}

Samples were collected from Malacca city, whereby the location of the city is shown in Figure 1, detailing the soil formation for the Peninsular Malaysia [15]. It is found that soil is formed from Marine alluvium, which was derived from high grade metamorphic and sedimentary rocks. The sample was obtained at a depth of 2.5 meters from the ground surface of the Malacca riverbanks, whilst the water level was at $1.0 \mathrm{~m}$ depth from the ground surface. It was also observed that the roots of plants within the area are extended to about $1.0 \mathrm{~m}$ deep from the ground surface. During sample collection, the soil was initially very stiff before becoming loose after some time and as the water was squeezed out from the soil. It is observed that the color of the samples was dark grey and emanated a bad smell, indicative of the presence of organic matter. The samples were kept in a sealed bucket to maintain its initial condition before any tests can be conducted. Sieve analysis, hydrometer test, Atterberg limits, oedometer test, and specific gravity, and micromechanical testing, which is $\mathrm{X}$-ray fluorescence XRF test, were conducted to investigate the physical, mechanical and microstructural characteristics of the samples taken.

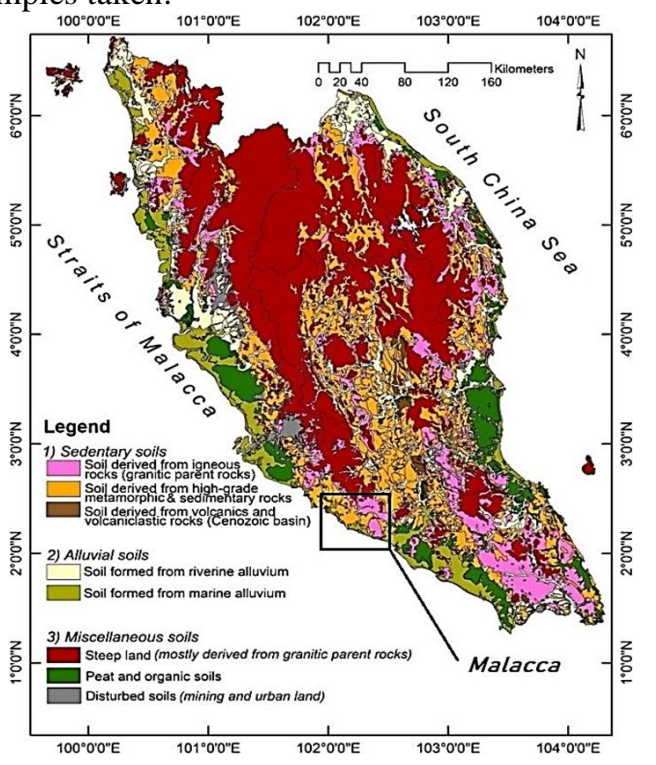

Figure 1: Malacca's location on the geological map for Peninsular

\section{RESULTS} Malaysia [15]

\subsection{Soil Formation}

Sieve analysis was applied to the samples according to the instructions of D422-63R98, ASTM [22], which indicated grain size distribution of $16.3 \%$ (gravel), $52.3 \%$ (sand), and $31.4 \%$ (fines), see Figure 2. The chart illustrates that the major of the soil's granular components to be about fine by $50 \%$, directly revealing its hydraulic conductivity to be extremely low in the presence of $31.4 \%$ fines. The soil classification is characterized as SM silty sand soil, according to the Unified Soil Classification System (USCS) as per D2487-00, ASTM [23]. A hydrometer test, which was conducted according to the instructions of D422-63R98, ASTM [22] on the $31.4 \%$ fines showed that grain size distribution consists of $15.4 \%$ silt and $16 \%$ clay. Thus, major of the fines are clay by $50.95 \%$. This is again depicted in Figure 2.

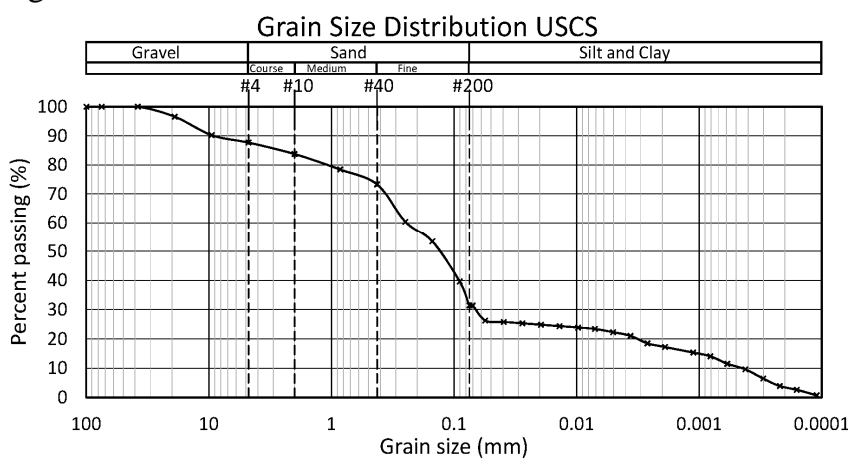

Figure 2: Full-grain size distribution for both coarse soil and fines for the samples collected

\subsection{Fines Activity}

The test to identify the Atterberg limits indicated a liquid limit of $63.66 \%$ and a plastic limit of $32.57 \%$, see Table 1 . The value of the plasticity index was very high by $31.10 \%$ in which the consistency index was -0.10 , indicating that the soil behavior followed the liquid state and was very soft, according to Equation 1.

$$
C I=w_{L L}-w_{n} / w_{L L}-w_{P L}
$$

Such an explanation elucidated the soil instability seen during loading and the resultant huge deformations. According to the limits, the fines were classified as silt with high plasticity $\mathrm{MH}$, or organic clays or organic silts $\mathrm{OH}$ as per the Casagrande plasticity chart shown in Figure 3.

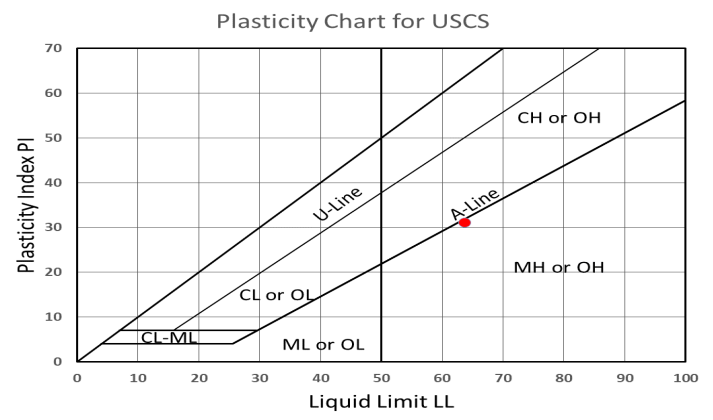

Figure 3: Fines classification using Atterberg limits as per USCS classification

The natural water content encountered was found to be $67 \%$, which was higher than the liquid limit of the samples. It sufficiently explained the unstable behavior of the soil from Malacca City. Table 1 indicates that the Atterberg limits and natural water content $w_{n}$ for Malacca soil follow the same tendency for southeast Asia marine clays. 
Ahmed Hassan Saad et al., International Journal of Emerging Trends in Engineering Research, 8(10), October 2020, 7232 - 7241

Table 1. Natural water content, liquid limit, plastic limit, and plasticity index for previous and current research

\begin{tabular}{|c|c|c|c|c|c|c|}
\hline Location & Country & $w_{n}(\%)$ & $\mathrm{w}_{\mathrm{LL}}(\%)$ & $\mathrm{w}_{\mathrm{PL}}(\%)$ & PI (\%) & Source \\
\hline Malacca & Malaysia & 67 & 63.66 & 32.57 & 31.09 & - \\
\hline Bangkok & Thailand & $38-92$ & $68-102$ & $28-39$ & $38-64$ & [7] \\
\hline Klang & Malaysia & 59 & 63.66 & 49.66 & 14 & [24] \\
\hline Johor & Malaysia & 59 & 41 & 22 & 19 & [20] \\
\hline Kalang & Malaysia & $98-103$ & $61.5-80$ & $35-49$ & $26.5-31$ & [8] \\
\hline Changi & Singapore & $10-88$ & $38-95$ & $13-31$ & $20-67$ & [25] \\
\hline UTHM & Malaysia & - & 60.84 & 36.7 & 24.14 & [17] \\
\hline Changi & Singapore & $10-88$ & $50-95$ & $18-30$ & $30-67$ & [9] \\
\hline Yarra Delta. & Australia & $56.7-73.6$ & $65-75$ & $31-47$ & $26-37$ & [6] \\
\hline Changi East & Singapore & $43-75$ & $63-84$ & $21-27$ & $42-58$ & [26] \\
\hline Pusan & South Korea & $28-85$ & $28-70$ & $10-42$ & $15-41$ & [27] \\
\hline Mekong & Vietnam & $60-95$ & $60-80$ & $30-40$ & $30-40$ & [28] \\
\hline Hong Kong & Hong Kong & $34-90$ & $34.7-76.5$ & $16.6-45.2$ & $18.1-31.1$ & [12] \\
\hline Oita prefecture & Japan & $126.2-141.3$ & - & - & - & {$[2]$} \\
\hline- & - & $41-120$ & $34-122$ & $14-41$ & $13-92$ & [29] \\
\hline Johor & Malaysia & $45-100$ & $55-102$ & $20-42$ & $35-63$ & {$[30]$} \\
\hline Erzurum & Turkey & - & 72 & 33 & 39 & [31] \\
\hline Sabak & Malaysia & 80 & 79 & 31 & 48 & {$[10]$} \\
\hline Shanghai & China & $32-55$ & $33-43$ & $19-22$ & $13-21$ & [32] \\
\hline Singapore & Singapore & $20-74$ & $35-113$ & $16-44$ & $19-83$ & {$[33]$} \\
\hline Penang & Malaysia & - & 47 & 28 & 19 & [21] \\
\hline Johor & Malaysia & - & 58 & 23 & 35 & [34] \\
\hline Ariake & Japan & $72-166$ & $60-140$ & $15-50$ & $25-94$ & [4] \\
\hline Bangkok & Thailand & $42-135$ & $78-142$ & $17--75$ & $25-125$ & [4] \\
\hline- & Malaysia & $25-110$ & $50-120$ & $20-35$ & $30-85$ & [1] \\
\hline Ashikari & Japan & $90-150$ & $68-115$ & $26-41$ & $28-75$ & [35] \\
\hline Kelang & Malaysia & $58-98$ & $71-114$ & $32-48$ & $32-67$ & {$[5]$} \\
\hline Batu Pahat & Malaysia & - & 61 & 36 & 25 & [36] \\
\hline Klang & Malaysia & $35-140$ & $96-150$ & $20-85$ & $41-130$ & {$[37]$} \\
\hline Ariake & Japan & $90-150$ & $65-130$ & $40-100$ & $25-45$ & {$[3]$} \\
\hline Singapore & Singapore & $50-60$ & $65-80$ & $40-60$ & $20-25$ & [3] \\
\hline Bangkok & Thailand & $55-80$ & $45-85$ & $30-70$ & $15-25$ & {$[3]$} \\
\hline Osaka & Japan & $36.6-69.1$ & $82.4-100.4$ & $32.7-37.8$ & $46.7-62.6$ & {$[38]$} \\
\hline Chinese Cities & China & $18.4-80.1$ & $28.36-86$ & $6.53-48$ & $6.92-55$ & [39] \\
\hline Dalian City & China & $46.6-63.7$ & $28.6-49.2$ & $16.1-30.7$ & $12.5-18.7$ & [13] \\
\hline
\end{tabular}

Based on data analysis, the Malacca soil followed the soil parameters of South East Asia marine clays for locations in Malaysia like in Klang and Johor (Batu Pahat and UTHM), as well as in Singapore marine clays. Table 1 shows that the $\mathrm{w}_{\mathrm{n}}$ range is between $10-166 \%$ and its average is $74.15 \%$, whereas the liquid limit $\mathrm{w}_{\mathrm{LL}}$ range is between $28-150 \%$ and its average is $75.3 \%$, while the plastic limit $\mathrm{w}_{\mathrm{PL}}$ range is between $6.53-100 \%$ and its average is $35 \%$. Meanwhile, the plasticity index PI range is between 6.92 - 130, and its average is 41.55 .

\subsection{Soil Compressibility}

One dimensional (1D) consolidation test was undertaken using an oedometer apparatus as per D-2435-96, ASTM (1996) instructions. Remolded samples were used where water content is equaled to the natural water content $\mathrm{w}_{\mathrm{n}}$ and in the dimensions of $50 \mathrm{~mm}$ (diameter) and $14.79 \mathrm{~mm}$ (height). The stresses applied for loading were 12.5, 25, 100, and 200 $\mathrm{kPa}$, whereas unloading stresses were valued at 50 and 12.5 $\mathrm{kPa}$. Results showed that the compression index, $\mathrm{C}_{\mathrm{c}}$, and recompression (swelling) index, $\mathrm{C}_{\mathrm{r}}$ were 0.2811 and 0.0576 , respectively. From the relationship shown in Figure 4 between void ratio and vertical effective stress e $-\log \mathrm{P}_{\mathrm{c}}$, , the value of preconsolidation stress is determined to be equal to $42.17 \mathrm{kPa}$.

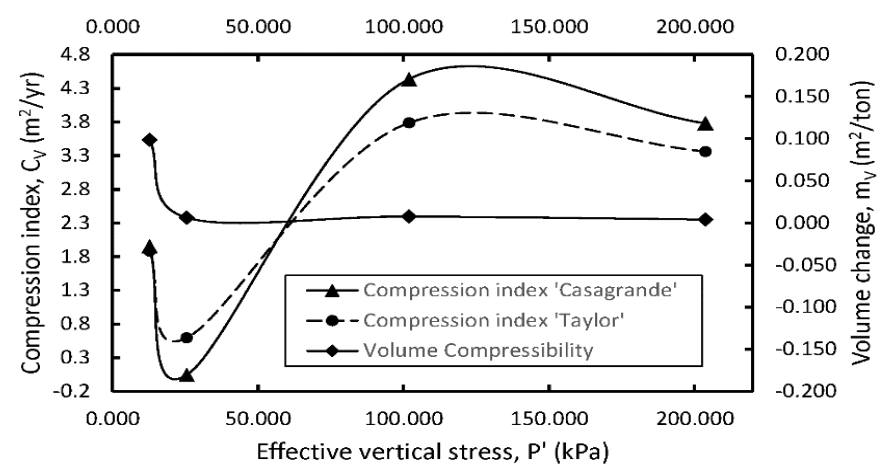

Figure 4: The relationship between vertical consolidation factor, $\mathrm{C}_{\mathrm{v}}$, and coefficient of volume compressibility, mv with preconsolidation pressure $\mathrm{P}_{\mathrm{c}}$ '. 
Consolidation coefficient, $\mathrm{C}_{\mathrm{v}}$ ranged from 1.952 to 4.435 $\mathrm{m}^{2} / \mathrm{yr}$. This is as shown in Figures 5 and 6. The coefficient of vertical consolidation $\mathrm{C}_{\mathrm{v}}$ relationship with effective vertical stresses $\mathrm{P}_{\mathrm{c}}$ ' is not linear; it follows a power equation curve, as shown in Figure 6.

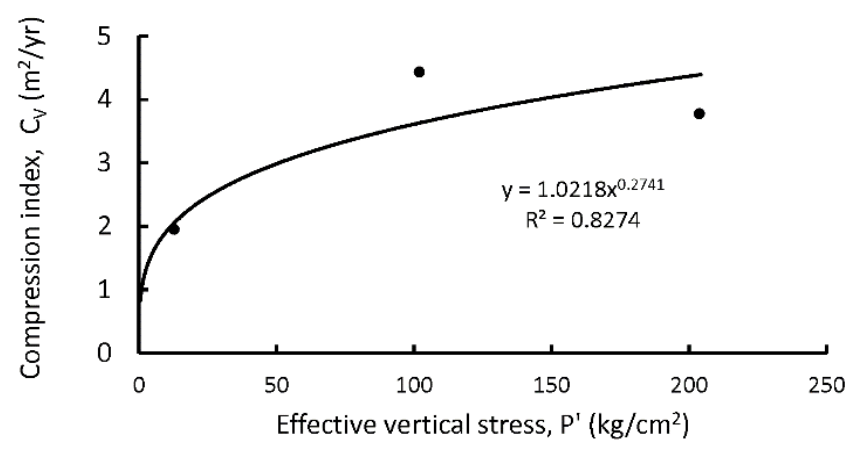

Figure 5: The relationship between the vertical coefficient of consolidation and the effective vertical stress

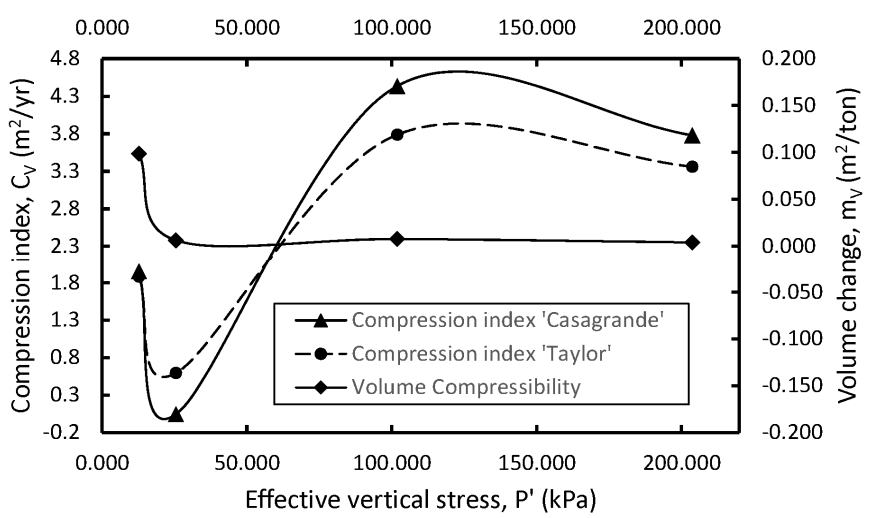

Figure 6: The relationship between vertical consolidation factor, $C_{v}$, and coefficient of volume compressibility, $\mathrm{m}_{\mathrm{v}}$ with preconsolidation pressure $\mathrm{P}_{\mathrm{c}}$ '.
A comparison of lab results obtained with other marine clays values, as displayed in Table 2 has revealed the following outcomes. The range of consolidation coefficient, $\mathrm{C}_{\mathrm{v}}$ ranged from $0.15-25 \mathrm{~m}^{2} / \mathrm{yr}$ and averaged at $3.780 \mathrm{~m}^{2} / \mathrm{yr}$, the compression index, $C_{c} 0.08-2.25$ and averaged at 0.948 , the recompression index (swelling index) $\mathrm{C}_{\mathrm{r}} 0.010-0.311$ averaged 0.174 , and yield (preconsolidation) stress $\mathrm{P}_{\mathrm{c}}{ }^{\prime} 23$ $320 \mathrm{kPa}$ and averaged at $103.54 \mathrm{kPa}$.

This showed that the Malacca marine clay values were within the average value for the other marine clays. Furthermore, the soil compressibility is a function of the Atterberg limits, and the results obtained are a reflection of the same results displayed in Section 3.2.

The water content for the tested samples was found to be equaled to $38.25 \%$. The permeability of the soil was predicted using Equation 2 [40]. A graph drawn for the relationship between permeability $\mathrm{k}$ and void ratio $\mathrm{e}_{\mathrm{o}}$ shows that the relationship is not linear, as seen in Figure 7.

$k=C_{V} \cdot m_{v} \cdot \gamma_{w}$

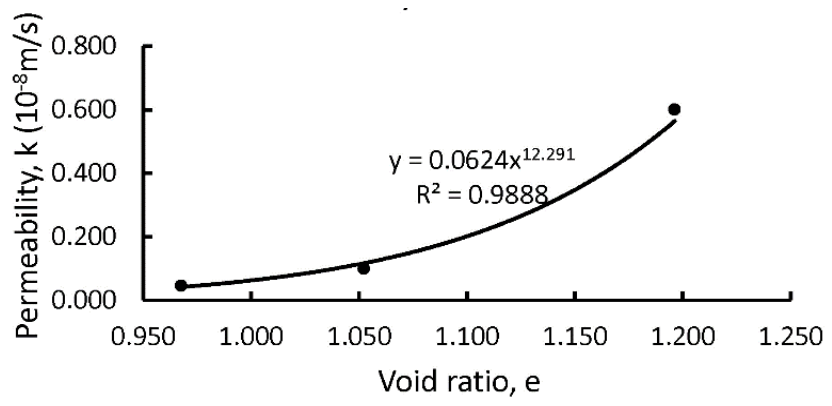

Figure 7: Relationship between permeability k and void ratio $\mathrm{e}_{\mathrm{o}}$.

Table 2: Natural water content, liquid limit, plastic limit, and plasticity index for previous and current research

\begin{tabular}{ccccccc}
\hline Location & Country & $\mathbf{P}_{\mathbf{c}}{ }^{\prime}(\mathbf{k P a})$ & $\mathbf{C}_{\mathbf{c}}$ & $\mathbf{C}_{\mathbf{r}}$ & $\mathbf{C}_{\mathbf{v}}\left(\mathbf{m}^{2} / \mathbf{y r}\right)$ & Source \\
\hline Malacca & Malaysia & 42 & 0.281 & 0.0576 & 2.9 & - \\
Changi & Singapore & $60-250$ & $0.2-1.7$ & $0.08-0.2$ & $0.47-4.5$ & {$[25]$} \\
Changi & Singapore & - & $0.2-1.5$ & $0.08-0.2$ & $0.47-4.5$ & {$[9]$} \\
Ariake & Japan & - & - & - & 3.65 & {$[3]$} \\
Singapore & Singapore & - & - & - & 1.095 & {$[3]$} \\
Bangkok & Thailand & - & - & - & 0.365 & {$[3]$} \\
Yarra Delta. & Australia & 38 & $0.594-1.352$ & - & - & {$[6]$} \\
Changi East & Singapore & $42-205$ & $0.45-1.4$ & - & - & {$[26]$} \\
Pusan & South Korea & $23-230$ & - & - & - & {$[27]$} \\
Oita prefecture & Japan & 42.1 & - & - & - & {$[2]$} \\
Mekong & Vietnam & - & $0.8-1.0$ & $0.27-0.3$ & - & {$[28]$} \\
Hong Kong & Hong Kong & - & $0.42-1.05$ & - & $1.9-3.1$ & {$[12]$} \\
Johor & Malaysia & $25-115$ & $0.55-2.25$ & - & - & {$[30]$} \\
Sabak & Malaysia & - & 0.614 & 0.169 & 0.93 & {$[10]$} \\
- & Malaysia & $30-110$ & $0.9-2.2$ & $0.01-0.2$ & $0.95-6.94$ & {$[1]$} \\
Kelang & Malaysia & - & $0.525-1.102$ & $0.098-0.311$ & $0.45-6.03$ & {$[5]$} \\
Chinese Cities & China & - & $0.08-1.03$ & - & - & {$[39]$} \\
Klang & Malaysia & $25-320$ & - & - & $0.15-25$ & {$[37]$} \\
\hline
\end{tabular}




\subsection{Specific Gravity and Density}

Specific gravity for the samples was determined following D854-00R02, ASTM [41], where its value was found to be 2.57. Bulk density Jbulk range and dry density $y_{\text {dry }}$ were subsequently determined by the values of $15.8-16.5 \mathrm{kN} / \mathrm{m}^{3}$ and $9.44-9.88 \mathrm{kN} / \mathrm{m}^{3}$, respectively .Collected data in Table 3 shows the range of specific gravity $\mathrm{G}_{\mathrm{s}}$, which is $2.13-2.80$ and averaged at 2.60. The Malacca soil followed the same tendency, especially for the Batu Pahat marine clay range [8]. Moreover, the bulk density of the Malacca marine clay also followed the general tendency, despite the range found to be between $15.8-16.5 \mathrm{kN} / \mathrm{m}^{3}$ and was relatively high compared to other ranges. This issue may be due to the fact that major of the previous research had not mentioned the level of samples taken, rendering it difficult to compare the data. Nevertheless, the value is not out of the range, as can be seen in Table 3 .

Table 3. Bulk density and specific gravity for previous and current research

\begin{tabular}{|c|c|c|c|c|}
\hline Location & Country & Ybulk $\left(\mathrm{kN} / \mathrm{m}^{3}\right)$ & $\mathbf{G}_{\mathrm{s}}$ & Reference \\
\hline Malacca & Malaysia & $15.80-16.50$ & 2.57 & - \\
\hline Bangkok & Thailand & $14.80-17.202$ & $2.64-2.68$ & [7] \\
\hline Klang & Malaysia & - & 2.39 & [24] \\
\hline Johor & Malaysia & - & 2.52 & [20] \\
\hline Batu Pahat & Malaysia & $14.00-16.002$ & $2.55-2.67$ & [8] \\
\hline Changi & Singapore & $14.23-19.602$ & $2.60-2.76$ & [25] \\
\hline UTHM & Malaysia & - & 2.60 & [17] \\
\hline Changi & Singapore & $14.20-19.602$ & $2.60-2.76$ & [9] \\
\hline Yarra Delta. & Australia & $15.00-16.002$. & $2.40-2.61$ & [6] \\
\hline Pusan & South Korea & $14.80-18.502$ & $2.63-2.73$ & [27] \\
\hline Oita & Japan & $13.10-15.402$ & $2.13-2.65$ & [2] \\
\hline- & - & 2. & $2.63-2.80$ & [29] \\
\hline Mekong & Vietnam & $14.00-16.00$ & - & [28] \\
\hline Hong Kong & Hong Kong & $14.60-17.60$ & - & [12] \\
\hline Sabak & Malaysia & 14.74 & 2.35 & [10] \\
\hline Penang & Malaysia & - & 2.42 & [21] \\
\hline Johor & Malaysia & $14.00-17.50$ & - & [30] \\
\hline Johor & Malaysia & 16.00 & - & [34] \\
\hline- & Malaysia & $14.00-17.002$ & $2.52-2.72$ & [1] \\
\hline Batu Pahat & Malaysia & - & 2.60 & [36] \\
\hline Klang & Malaysia & $14.42-15.48$ & - & [5] \\
\hline Klang & Malaysia & $12.70-18.80$ & - & [37] \\
\hline Dalian City & China & $16.80-18.50$ & - & [13] \\
\hline Ariake & Japan & - & $2.60-2.63$ & [3] \\
\hline Singapore & Singapore & - & $2.76-2.78$ & [3] \\
\hline Bangkok & Thailand & - & $2.72-2.75$ & [3] \\
\hline Osaka & Japan & 2. & $2.66-2.70$ & [38] \\
\hline Erzurum & Turkey & - & 2.62 & [31] \\
\hline
\end{tabular}

\subsection{Chemical Composition}

For Malacca marine clay, chemical composition for a dry sample was identified using $\mathrm{X}$-ray fluorescence XRF. The results of XRF is shown that $\mathrm{SiO}_{2}, \mathrm{Al}_{2} \mathrm{O}_{3}, \mathrm{Fe}_{2} \mathrm{O}_{3}, \mathrm{~K}_{2} \mathrm{O}, \mathrm{SO}_{3}$, and $\mathrm{MgO}$ are the major chemical component of the clay by $56.23 \%, 22.81 \%, 11.29 \%, 2.82 \%, 1.92 \%$, and $1.55 \%$, respectively.

\section{DISCUSSION}

This paper serves as a comparison between studied marine clay and several types of marine clay samples taken from various South East Asian locations [1]-[10], [12], [13], [16], [17], [20], [21], [24]-[35], [37]-[39], [42]. Significant variations of the geotechnical parameters have been found for the same region, even if not of the same borehole. Such variation is due to the different conditions of partial soil deposition during the process of soil layer formation.

Despite these variations, the results have displayed a common tendency for their respective soil behavior: high values of void ratio, its range is 0.63 .7 with average to 1.875 . Furthermore, comparing the value of compression index $\mathrm{C}_{\mathrm{c}}$ from the 1-D consolidation test has equaled to 0.281 across equations shown in Table 4 [43]-[46], which is a significant difference even in the case of the remolded clay equation [45]. Therefore, more readings are required to predict a relationship for compression index $\mathrm{C}_{\mathrm{c}}$, and liquid limit $\mathrm{w}_{\mathrm{LL}}$ or/and reduce the diversion with the curves formed by the equations in Table 5 [43]-[46].

Table 4. Compression index $\mathrm{C}_{\mathrm{c}}$ for different equations

\begin{tabular}{lcc}
\hline \multicolumn{1}{c}{ Equation } & $\mathbf{C}_{\mathbf{c}}$ & Source \\
\hline $\mathrm{C}_{\mathrm{c}}=0.009\left(\mathrm{w}_{\mathrm{LL}}-10\right)$ & 0.483 & {$[44]$} \\
$\mathrm{C}_{\mathrm{c}}=0.005\left(\mathrm{w}_{\mathrm{LL}}+71.8\right)$ & 0.677 & {$[43]$} \\
$\mathrm{C}_{\mathrm{c}}=0.007\left(\mathrm{w}_{\mathrm{LL}}-10\right)$ & 0.376 & {$[45]$} \\
$\mathrm{C}_{\mathrm{c}}=0.0128 \mathrm{w}_{\mathrm{LL}}-0.008 \mathrm{PI}-0.1423$ & 0.424 & {$[46]$} \\
\hline
\end{tabular}

Similarly, parameters like water content $\mathrm{w}_{\mathrm{n}}$, liquid limit $\mathrm{w}_{\mathrm{LL}}$, plastic limit $\mathrm{w}_{\mathrm{PL}}$, plasticity index PI, coefficient of consolidation $\mathrm{C}_{\mathrm{v}}$, small values of permeability $\mathrm{k}$ and bulk density ybulk have been shown in Tables 1 and 2, and Figure 7 and Table 3, respectively. Some results have displayed odd values compared to the general tendencies seen for Arkine of Japan [2]-[4], Ashikari (Japan) [35], Oita Prefecture (Malaysia) [2], and Klang (Malaysia) [24]. Nevertheless, the value of liquid limit $\mathrm{w}_{\mathrm{LL}}$ is found to be not less than $60 \%$ [3], [30], [35]; whereas the plastic limit $\mathrm{w}_{\mathrm{PL}}$ is below 30\% [9], [10], [17], [20], [21], [32], [34], [37]. Similarly, the natural water content wn is within the range of liquid limit if not higher [4], [5], [7], [10], [12], [16], [17], [20], [30], [32], [39].

Therefore, a comparison of the obtained soil parameters for Malacca marine clay with soil parameters of other works has revealed that the Malacca marine clay displays values that are within the range of clay parameters from Johor of Malaysia [30], [34], Kalang (Malaysia) [8], Changi (Singapore) [9], 
Ahmed Hassan Saad et al., International Journal of Emerging Trends in Engineering Research, 8(10), October 2020, 7232 - 7240

[26], Bangkok (Thailand) [7], Pusan (South Korea) [27], and Yarra Delta (Australia) [6].

Due to the weakness and the random behavior of marine clay, it has to be treated before any construction work can be done. One of the major common solutions is soil stabilization by physical, chemical, or biological treatment, or a combination of two or more of them, see Table 5 .Each method is limited by specific restrictions that may match the case study which is based on the size of the project, required scale of application, cost, time, and environmental restrictions. Nevertheless, every method enhances the treated soil properties in varied ranges and/or focusing on different influencing factors.

Table 5 Categorized Comparison for different marine clay treatment methods

\begin{tabular}{|c|c|c|c|}
\hline$\sum_{k}^{\infty}$ & Treatment method & Disadvantages & Advantages \\
\hline \multirow{3}{*}{ 宽 } & $\begin{array}{l}\text { Thermal treatment } \\
\text { [7] }\end{array}$ & $\begin{array}{l}\text { - Energy wasting } \\
\text { - Limited conditions to be able for applying as } \\
\text { surrounding temperature, moisture content, soil } \\
\text { conductivity, etc. }\end{array}$ & $\begin{array}{l}\text { - Enhances soil consolidation } \\
\text { - Almost completed consolidation in period } \\
\text { of } 105 \text { days }\end{array}$ \\
\hline & $\begin{array}{l}\text { Electro-kinetic } \\
\text { stabilization [17] }\end{array}$ & $\begin{array}{l}\text { - - New method that needs more experiments and } \\
\text { data to get better estimation for requirements } \\
\text { and its effect } \\
\text { - Electric energy consuming increases for large } \\
\text { zones to cover } \\
\text { - Disturb pH, mineralogy and minerals inside soil } \\
\text { texture because of force migration due to } \\
\text { electric potential effect }\end{array}$ & $\begin{array}{l}\text { - Significantly increased strength especially } \\
\text { in the vicinity of the cathode } \\
\text { - Electroosmosis process increases soil pore } \\
\text { water pressure that increased soil shear } \\
\text { strength }\end{array}$ \\
\hline & cuum preloading & $\begin{array}{l}\text { the targeted strength; one } \\
\text { from } 4 \mathrm{kPa} \text { to } 50 \mathrm{kPa}\end{array}$ & out 10 times \\
\hline \multirow{4}{*}{ 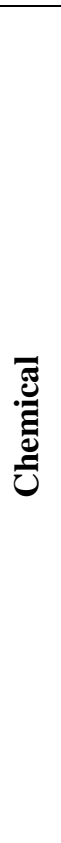 } & $\begin{array}{l}\text { RBT (recycled } \\
\text { blended tiles) [20] }\end{array}$ & $\begin{array}{l}\text { - Very hard to apply in large scale because of } \\
\text { mixing process limitation } \\
\text { - For required strength a required RBT sizes are } \\
\text { needed that could make uncertainties in shear } \\
\text { strength due to mistakes in preparation of the } \\
\text { mixture }\end{array}$ & $\begin{array}{l}\text { - Decreases liquid limit, plastic limit and } \\
\text { plasticity index } \\
\text { - Significantly increase in maximum dry } \\
\text { density and decrease in OMC }\end{array}$ \\
\hline & $\begin{array}{l}\text { Treated coir fibers } \\
{[8]}\end{array}$ & $\begin{array}{l}\text { - Hard to apply in large scale because of mixing } \\
\text { process limitation } \\
\text { - For required strength a required coir fibers sizes } \\
\text { are needed that could make uncertainties in } \\
\text { shear strength due to mistakes in preparation of } \\
\text { the mixture }\end{array}$ & $\begin{array}{l}\text { - Enhances strength and mechanical } \\
\text { behavior, depending on fiber content and } \\
\text { curing time } \\
\text { - Fiber inclusion significantly increased } \\
\text { tensile strength }\end{array}$ \\
\hline & $\begin{array}{l}\text { Nanoma } \\
\text { addition }\end{array}$ & $\begin{array}{l}\text { - Hard to apply in large scale because of mixing } \\
\text { process limitation } \\
\text { - For required strength a required nanomaterial } \\
\text { additions sizes are needed that could make } \\
\text { uncertainties in shear strength due to mistakes } \\
\text { in preparation of the mixture }\end{array}$ & $\begin{array}{l}\text { - Liquid limit, plastic limit, plasticity index, } \\
\text { and linear shrinkage decreased } \\
\text { - Increase in compressive strength }\end{array}$ \\
\hline & Cement mixing [6] & $\begin{array}{l}\text { - Underestimation of the stiffness using external } \\
\text { strain measurements }\end{array}$ & $\begin{array}{l}\text { - UC strength increase with increasing } \\
\text { amount of cement content }\end{array}$ \\
\hline 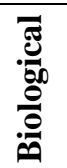 & Biomass Silica [34] & $\begin{array}{l}\text { - Increased plastic limits with Biomass Silica } \\
\text { increase }\end{array}$ & $\begin{array}{l}\text { - Decreased liquid limit with Biomass Silica } \\
\text { increase } \\
\text { - Biomass Silica is stabilizing agent }\end{array}$ \\
\hline
\end{tabular}




\begin{tabular}{|c|c|c|c|}
\hline \multirow[t]{2}{*}{ 莺 } & $\begin{array}{l}\text { Electro-Osmotic } \\
\text { Chemical } \\
\text { Treatment Using } \\
\mathrm{CaCl}_{2} \text { Solution [13] }\end{array}$ & $\begin{array}{l}\text { - Electric energy consuming increases for large } \\
\text { zones to cover and increases with the increase of } \\
\text { the concentration of the injected } \mathrm{CaCl}_{2} \text { solution } \\
\text { - For more efficiency consuming more } \mathrm{CaCl}_{2} \text { is } \\
\text { required to increase the dewatering } \\
\text { - Disturb pH, mineralogy and minerals inside soil } \\
\text { texture because of force migration due to } \\
\text { electric potential effect }\end{array}$ & $\begin{array}{l}\text { - Speeds dewatering and the dewatering } \\
\text { efficiency } \\
\text { - Improved bearing capacities of soils in four } \\
\text { tests }\end{array}$ \\
\hline & $\begin{array}{l}\text { Sand compacted } \\
\text { piles [12] }\end{array}$ & $\begin{array}{l}\text { - Upheaval soil clearly removed during installation } \\
\text { with a high replacement area ratio }\end{array}$ & $\begin{array}{l}\text { - Improved soil strength and settlements } \\
\text { significantly decreased } \\
\text { - During construction period most of } \\
\text { settlement occurred }\end{array}$ \\
\hline
\end{tabular}

\section{CONCLUSION}

The laboratory tests conducted indicated that the marine clay samples collected from Malacca to be classified as silty sand, according to the USCS. The geotechnical parameters obtained include: liquid limit (63.66\%), natural water content (67\%), plastic limit (32.57\%), compression index $\mathrm{C}_{\mathrm{c}}(0.281)$, recompression (swelling) index $\mathrm{C}_{\mathrm{r}}(0.0576)$, coefficient of vertical consolidation $\mathrm{C}_{\mathrm{v}}\left(0.043-4.435 \mathrm{~m}^{2} / \mathrm{yr}\right)$, specific gravity $\mathrm{G}_{\mathrm{s}}(2.57)$, bulk density ybulk $\left(15.8-16.5 \mathrm{kN} / \mathrm{m}^{2}\right)$, dry density $\gamma_{\text {dry }}(9.46-9.88 \mathrm{kN} / \mathrm{m} 2)$, permeability for fines only was $\mathrm{k}\left(6.3 \times 10^{-9}\right.$ to $\left.6.0 \times 10^{-7} \mathrm{~m} / \mathrm{yr}\right)$, and preconsolidation stress $\mathrm{Pc}^{\prime} 42.17 \mathrm{kPa}$. $\mathrm{SiO}_{2}, \mathrm{Al}_{2} \mathrm{O}_{3}$ and $\mathrm{Fe}_{2} \mathrm{O}_{3}$ were found to be main compounds of Malacca marine clay by $56.23 \%, 22.81 \%$ and $11.29 \%$ respectively.

Based on the obtained results and comparison made with marine clay from previous research, Malacca marine clay was found to be following the same tendencies and behavior of other marine clays, which indicates the applicability of some of the proposed methods of treatment. However, each treatment method possessed their own respective limitation that may match the case study based on the size of the project, required scale of application, cost, time, and environmental restrictions. Its void ratio was also displayed to be very high, which is indicative of a high probability for failure and significant deformations under loading in the future. However, the values obtained from the tests were insufficient in estimating equations that describe the tendency of the parameters or to allow a comparison with other equations. Therefore, more readings are required in the future to encapsulate more sample behavior.

\section{ACKNOWLEDGEMENT}

This study is a part of a project that has been funded by Putra Grant Scheme (Geran Putra), grant number GP/2018/9635200.

\section{REFERENCES}

1. H. G. Poulos, C. Y. Lee, and J. C. Small, Prediction of embankment performance on Malaysian marine clays, Int. Symp. trial embankments Malaysian Mar. clays., no. 1987, pp. 22-31, 1989.

2. Z. Hong, Y. Tateishi, and J. Han, Experimental Study of Macro- and Microbehavior of Natural Diatomite, $J$. Geotech. Geoenvironmental Eng., Vol. 132, no. 5, pp. 603-610, Apr. 2006.

3. H. Tanaka, J. Locat, S. Shibuya, T. T. Soon, and D. R. Shiwakoti, Characterization of Singapore, Bangkok, and Ariake clays, Can. Geotech. J., Vol. 38, no. 2, pp. 378-400, Apr. 2001.

4. M. Ohtsubo, K. Egashira, T. Koumoto, and D. Bergado, Mineralogy and Chemistry, and Their Correlation with the Geotechnical Index Properties of Bangkok Clay. Comparison with Ariake Clay., SOILS Found., Vol. 40, no. 1, pp. 11-21, Oct. 2000.

5. M. R. Taha, J. Ahmed, and S. Asmirza, One-dimensional consolidation of Kelang clay, Pertanika J. Sci. Technol., Vol. 8, no. 1, pp. 19-29, 2000.

6. A. Bouazza, P. S. Kwan, and G. Chapman, Strength properties of cement treated Coode Island silt by the soil mixing method, in Geotechnical Engineering for Transportation Projects, 2004, pp. 1421-1428.

7. H. M. Abuel-Naga, D. T. Bergado, A. Bouazza, and M. J. Pender, Thermal conductivity of soft Bangkok clay from laboratory and field measurements, Eng. Geol., Vol. 105, no. 3-4, pp. 211-219, May 2009.

8. V. Anggraini, B. B. K. Huat, A. Asadi, and H. Nahazanan, Effect of Coir Fibers on the Tensile and Flexural Strength of Soft Marine Clay, J. Nat. Fibers, Vol. 12, no. 2, pp. 185-200, Mar. 2015.

9. M. W. Bo, A. Arulrajah, P. Sukmak, and S. Horpibulsuk, Mineralogy and geotechnical properties of Singapore marine clay at Changi, Soils Found., Vol. 55, no. 3, pp. 600-613, Jun. 2015.

10. D. C. Lat et al., Compressibility characteristics of Sabak Bernam Marine Clay, IOP Conf. Ser. Mater. Sci. Eng., Vol. 342, no. 1, pp. 1-11, Apr. 2018.

11. Y. Deng, T. Zhang, Y. Cui, Y. Chen, T. Deng, and X. Zhou, Pore water salinity effect on the intrinsic 
compression behaviour of artificial soft soils, Appl. Clay Sci., Vol. 166, no. October, pp. 299-306, Dec. 2018.

12. H. He, Y. Lin, J. Li, and N. Zhang, Immersed tunnel foundation on marine clay improved by sand compaction piles, Mar. Georesources Geotechnol., Vol. 36, no. 2, pp. 218-226, Feb. 2018.

13. L. Zhang, L. Jing, N. Wang, C. Fang, Z. Shan, and Y. Li, Electro-Osmotic Chemical Treatment of Marine Clayey Soil Using CaCl2 Solution, in Proceedings of the 2nd International Symposium on Asia Urban GeoEngineering, no. 204379, Singapore: Springer, 2018, pp. 36-48.

14. Y. Shen, P. Zhao, and Q. Shao, Porous silica and carbon derived materials from rice husk pyrolysis char, Microporous Mesoporous Mater., Vol. 188, pp. 46-76, Apr. 2014.

15. Department of Agriculture Peninsular Malaysia, Map of Soil Types in Peninsular Malaysia. Department of Agriculture, Peninsular Malaysia, Kuala Lumpur, Malaysia, 2002.

16. W. Zhu, J. Yan, and G. Yu, Vacuum preloading method for land reclamation using hydraulic filled slurry from the sea: A case study in coastal China, Ocean Eng., Vol. 152, no. November 2017, pp. 286-299, Mar. 2018.

17. A. T. S. Azhar et al., The Physical Behavior of Stabilised Soft Clay by Electrokinetic Stabilisation Technology, J. Phys. Conf. Ser., Vol. 995, no. 1, pp. 1--11, Apr. 2018.

18. A. H. Saad, H. Nahazanan, Z. M. Yusoff, B. K. Huat, and M. Mustafa, Properties of Biomineralization Process in Various Types of Soil and Their Limitations, Int. J. Eng. Adv. Technol., Vol. 9, no. 1, pp. 4261-4268, Oct. 2019.

19. A. H. Saad, H. Nahazanan, Z. M. Yusoff, B. K. Huat, and M. Mustafa, Review: Marine clay in tropical regions and south asia, in 5th GEGEU International Research Seminar 2018, 2018, pp. 34-44.

20. M. A. M. Al-Bared, A. Marto, I. S. H. Harahap, and F. Kasim, Compaction and Plasticity Comparative Behaviour of Soft Clay Treated with Coarse and Fine Sizes of Ceramic Tiles, E3S Web Conf., Vol. 34, Mar. 2018.

21. Z. H. Majeed, M. R. Taha, Z. Hameed Majeed, and M. R. Taha, Effect of nanomaterial treatment on geotechnical properties of a Penang soft soil, J. Asian Sci. Res., Vol. 2, no. 11, p. 587, 2012.

22. ASTM, (D422-63R98) Standard test method for particle-size analysis of soils, 1998.

23. ASTM, (D2487-00) Standard practice for classification of soils for engineering purposes, 2000.

24. J. Ahmad, N. H. Md. Zain, Y. Ashaari, and A. S. Abdul Rahman, Lateral movement and settlement of sandwiched soft soil using physical model, in 2011 IEEE Colloquium on Humanities, Science and Engineering, Dec. 2011, pp. 71-75.

25. A. Arulrajah, H. Nikraz, and M. W. Bo, In-situ testing of
Singapore marine clay at Changi, Geotech. Geol. Eng., Vol. 23, no. 2, pp. 111-130, 2005.

26. J. Chu, M. W. Bo, M. F. Chang, and V. Choa, Consolidation and Permeability Properties of Singapore Marine Clay, J. Geotech. Geoenvironmental Eng., Vol. 128, no. 9, pp. 724-732, Aug. 2002.

27. S. G. Chung, K. N. Prasad, T. S. Nagaraj, J. G. Chung, and K. Y. Jo, Assessment of compressibility behavior of naturally cemented soft clays, Mar. Georesources Geotechnol., Vol. 22, no. 1-2, pp. 1-20, Jan. 2004.

28. P. H. Giao, N. T. Dung, and P. V. Long, An integrated geotechnical-geophysical investigation of soft clay at a coastal site in the Mekong Delta for oil and gas infrastructure development, Can. Geotech. J., Vol. 45, no. 11, pp. 1514-1524, Nov. 2008.

29. Z.-S. . Hong, L.-L. Zeng, Y.-J. Cui, Y.-Q. Cai, and C. Lin, Compression behaviour of natural and reconstituted clays, Géotechnique, Vol. 62, no. 4, pp. 291-301, Apr. 2012.

30. B. B. K. Huat, Behaviour of Soft Clay Foundation beneath an Embankment, Pertanika J. Sci. Technol., Vol. 2, no. October 1993, pp. 215-235, 1994.

31. Z. N. Kurt and S. Akbulut, Some geotechnical properties of clay nanocomposites, Period. Polytech. Civ. Eng., Vol. 61, no. 3, pp. 381-388, Dec. 2017.

32. X. Zhang and X. Gong, Observed Performance of a Deep Multistrutted Excavation in Hangzhou Soft Clays with High Confined Water, Adv. Mater. Res., Vol. 250-253, no. 8, pp. 2276-2280, May 2011.

33. H.-E. Low, K.-K. Phoon, T.-S. Tan, and S. Leroueil, Effect of soil microstructure on the compressibility of natural Singapore marine clay, Can. Geotech. J., Vol. 45, no. 2, pp. 161-176, Apr. 2008.

34. A. Marto, N. Z. Mohd Yunus, F. Pakir, N. Latifi, A. H. Mat Nor, and C. S. Tan, Stabilization of Marine Clay by Biomass Silica (Non-Traditional) Stabilizers, Appl. Mech. Mater., Vol. 695, pp. 93-97, Nov. 2014.

35. S.-L. Shen, J. Han, and Y.-J. Du, Deep Mixing Induced Property Changes in Surrounding Sensitive Marine Clays, J. Geotech. Geoenvironmental Eng., Vol. 134, no. 6, pp. 845-854, Jun. 2008.

36. S. A. A. Tajudin, M. A. M. Azmi, and A. T. A. Nabila, Stabilization/Solidification Remediation Method for Contaminated Soil: A Review, IOP Conf. Ser. Mater. Sci. Eng., Vol. 136, no. 1, p. 012043, Jul. 2016.

37. Y. C. Tan, S. S. Gue, H. B. Ng, and P. T. Lee, Some Geotechnical Properties of Klang Clay, in Proc. of Malaysian Geotechnical Conference, 2004, pp. 179-186.

38. Y. Watabe, K. Udaka, M. Kobayashi, T. Tabata, and T. Emura, Effects of Friction and Thickness on Long-Term Consolidation Behavior of Osaka Bay Clays, Soils Found., Vol. 49, no. 5, pp. 824-825, 2009.

39. Z. Wu, H. Ji, C. Yu, and C. Zhou, EPR-RCGA-based modelling of compression index and RMSE-AIC-BIC-based model selection for Chinese marine clays and their engineering application, $J$. Zhejiang Univ. A, Vol. 19, no. 3, pp. 211-224, Mar. 2018. 
40. F. H. F. H. Kulhawy and P. W. P. W. Mayne, Manual on Estimating Soil Properties for Foundation Design, Electric Power Research Inst., Palo Alto, CA (USA); Cornell Univ., Ithaca, NY (USA). Geotechnical Engineering Group, thaca, NY (USA), 1990.

41. ASTM, (D854-00R02) Standard Test Method for Specific Gravity of Soils, 2002.

42. S. A. A. Tajudin et al., the Monitoring and Cementation Behavior of Electrokinetic Stabilisation Technique on Batu Pahat Marine Clay, Int. J. Geomate, Vol. 11, no. 26, pp. 2581-2588, Jun. 2016.

43. B. K. Huat, K. Othman, and A. A. Jaafar, Geotechnical properties of Malaysian marine clays, J. Inst. Eng. Malaysia, Vol. 56, pp. 21-41, 1995.

44. N. Najdanovic and R. Obradovic, ( Soil mechanics in engineering practice)., 1981.

45. A. W. Skempton and O. T. Jones, Notes on the compressibility of clays, Q. J. Geol. Soc., Vol. 100, no. 1-4, pp. 119-135, Jan. 1944.

46. P. Dwivedi, R. Kumar, P. K. Jain, and P. Dwivedi, Prediction of compression index $(\mathrm{Cc})$ of fine grained remolded soils from basic soil properties, Int. J. Appl. Eng. Res., Vol. 11, no. 1, pp. 592-598, 2016. 